\title{
Differential Regulation of Eotaxin-1/CCL11 and Eotaxin-3/CCL26 Production by the TNF- $\alpha$ and IL-4 Stimulated Human Lung Fibroblast
}

\author{
Akiko Rokudai, ${ }^{a, b}$ Yasuhito Terui, ${ }^{a}$ Ryoko Kuniyoshi, ${ }^{a, b}$ Yuji Mishima, ${ }^{a}$ Yuko Mishima, ${ }^{a}$ \\ Eriko Aizu-Yokota, ${ }^{b}$ Yoshiko Sonoda, ${ }^{b}$ Tadashi Kasahara, ${ }^{*, b}$ and Kiyohiko Hatake ${ }^{*, a}$ \\ a Division of Clinical Chemotherapy, Cancer Chemotherapy Center, Japanese Foundation for Cancer Research; 3-10-6 \\ Ariake, Koutou-ku, Tokyo 135-8550, Japan: and ${ }^{b}$ Department of Biochemistry, Kyoritsu University of Pharmacy; 1-5-30 \\ Shibakoen, Minato-ku, Tokyo 105-8512, Japan. \\ Received October 7, 2005; accepted March 1, 2006; published online March 7, 2006
}

\begin{abstract}
Allergic asthma and allergic dermatitis are chronic inflammatory diseases and are characterized by an accumulation of eosinophils at sites of inflammation. Eotaxin-1/CCL11 and eotaxin-3/CCL26 are members of the CC chemokine family, which are known to be potent chemoattractants for eosinophils. We observed that a human lung fibroblast, HFL-1 produces eotaxin-1 and -3 in response to TNF- $\alpha$ plus IL-4 stimulation, accompanied with NF- $\kappa$ B and STAT6 activation. We explored which signaling pathways are operative in the production of eotaxin-1 and -3 using several inhibitors. Eotaxin-1/CCL11 production was inhibited by a p38 mitogen-activated protein kinase (MAPK) inhibitor, SB203580, but not by the MEK (MAPK/ERK kinase) inhibitors, PD98059 and U0126. In contrast, eotaxin-3/CCL26 production was inhibited similarly by PD98059 as well as U0126 and SB203580. In addition, two proteasome inhibitors, $N$-acetyl-leucyl-leucyl-norleucinal (ALLN) and bortezomib with significant inhibitory activity on NF- $\kappa B$ activation, inhibited eotaxin-1/CCL11 production with $\mathrm{IC}_{50} 8 \mu \mathrm{M}$ for $\mathrm{ALLN}$ and $\mathrm{IC}_{50} 16 \mathrm{~nm}$ for bortezomib. In contrast, eotaxin-3/CCL26 production was not inhibited significantly up to $10 \mu \mathrm{M}$ of $\mathrm{ALLN}\left(\mathrm{IC}_{50} 16 \mu \mathrm{M}\right)$ and up to $10 \mathrm{nM}$ of bortezomib $\left(\mathrm{IC}_{50} 11 \mathrm{nM}\right)$, giving inhibition of eotaxin-3/CCL26 less sensitive than eotaxin-1/CCL11 production by the proteasome inhibitors. Synergistic inhibition was observed among lower doses of SB203580 and proteasome inhibitors, particularly in the eotaxin1/CCL11 production. No such prominent synergism was found on the eotaxin-3/CCL26 production. The suppression of eotaxin family production by these inhibitors may be efficacious against allergic diseases.
\end{abstract}

Key words eotaxin-1; eotaxin-3; lung fibroblast; NF- $\kappa$ B activation; proteasome inhibitor

Chemokines are a family of small, structurally related proteins, essential for leukocyte trafficking and inflammatory diseases, ${ }^{1,2)}$ classified largely into two subgroups, CCchemokines and CXC-chemokines. ${ }^{3)}$ Of CC chemokines, eotaxin-1/CCL11 was discovered originally in a model of allergic lung inflammation of the guinea pig, ${ }^{4}$ and subsequently, eotaxin-2/CCL24 and eotaxin-3/CCL26 were cloned and also showed chemotactic activity for eosinophils as well as eotaxin-1. ${ }^{4-6)}$ Eotaxin-2/CCL24 and eotaxin-3/CCL26 were distantly related to eotaxin-1/CCL11 with approximately $30 \%$ homology in sequence and located on different chromosomes. ${ }^{6,7)}$

TNF- $\alpha$ activates NF- $\kappa \mathrm{B}$, a key regulator of immune and inflammatory genes, by inducing the phosphorylation and degradation of $\mathrm{I} \kappa \mathrm{B}$, which leads to the translocation of NF$\kappa \mathrm{B}$ to the nucleus where it can bind to specific promoter binding sites. ${ }^{8,9)}$ IL-4 is a pivotal cytokine associated with allergic disease that supports Th2 development and is produced by Th2 cells, basophils, and mast cells. ${ }^{10-12)} \mathrm{IL}-4$ has been shown to trigger tyrosine phosphorylation of a latent cytoplasmic transcription factor termed signal transducers and activators of transcription 6 (STAT6) via receptor-associated Janus kinase-1 (JAK1) and JAK3.

Interestingly, TNF- $\alpha$ and IL-4 appear to induce production of eotaxin-1/CCL11 in human dermal fibroblasts and airway epithelial cells in a synergistic fashion. ${ }^{13,14)}$ Eotaxin3/CCL26 is expressed in vascular endothelial cells after IL-4 and IL-13 stimulation. ${ }^{6)}$ The mechanism operative in regulating eotaxin-1/CCL11 expression was described such that TNF- $\alpha$ plus IL-4-stimulated eotaxin-1/CCL11 gene expression in epithelial cells was mediated by activation of tran- scription factors, NF- $\kappa \mathrm{B}$ and STAT6. ${ }^{15)}$ However, they did not show which transcription factor is a key in this signaling pathway. Recent studies have suggested that TNF- $\alpha$-induced $\mathrm{I} \kappa \mathrm{B} \alpha$ degradation was inhibited by a proteasome inhibitor (Z-Leu-Leu-leucinal (MG-132)) or the non-steroidal anti-inflammatory drug sodium salicylate $(\mathrm{NaSal}) . \mathrm{NF}-\kappa \mathrm{B}$ and p38MAPK play an important role in the TNF- $\alpha$-activated signaling pathway, regulating eotaxin release in eosinophils. ${ }^{16)}$ Our interest is to explore such pathways are also operative in the production of eotaxin-1/CCL11 and -3/ CCL26 in HFL-1 cells.

Proteasome inhibitors have recently emerged as an interesting and potentially new group of chemotherapeutic agents for a variety of human cancers including breast, prostate, and lung cancer. They function by stabilizing the $\mathrm{I} \kappa \mathrm{B} \alpha$ protein and then inhibiting NF- $\kappa \mathrm{B}$ activation. ${ }^{17)} N$-Acetyl-leucylleucyl-norleucinal (ALLN) can inhibit proteasome-associated activities at high concentrations. ${ }^{18)}$ More recently, a series of dipeptide boronic acid analog proteasome inhibitors that specifically inhibit the chymotryptic enzyme activity of the proteasome have been synthesized. ${ }^{19)}$ One of these, bortezomib (PS-341) is a small molecule and water-soluble dipeptide that targets the chymotryptic site in the $20 \mathrm{~S}$ proteasome. Recent reports have shown that bortezomib inhibits tumor cell growth by inhibiting NF- $\kappa \mathrm{B}$ activation, particularly in tumors constitutively expressing this pivotal transcription factor. $^{20,21)}$ No other effects of bortezomib have been explored in allergy or immune diseases.

In our preliminary studies, production of eotaxin-1/CCL11 and eotaxin-3/CCL26 but not eotaxin-2 was observed in a human primary lung fibroblast, HFL-1. In this study, we at- 
tempted to study how the production of eotaxin-1/CCL11 and -3/CCL26 is regulated in HFL-1 cells, particularly in terms of the role of the MEK/ERK and p38MAPK pathways. In addition, how the two proteasome inhibitors, ALLN and bortezomib suppress the eotaxin-1/CCL11 and -3/CCL26 production is studied to determine whether these drugs are useful as one of the future therapeutic agents for allergy and immune diseases.

\section{MATERIALS AND METHODS}

Cell Culture A human lung fibroblast, HFL-1 (RIKEN GENE BANK), was maintained at $37^{\circ} \mathrm{C}$ and $5 \% \mathrm{CO}_{2}$ on a collagen-coated dish in F-12 Nutrient Mixture medium (GIBCO) containing 15\% fetal bovine serum (Nippon BioSupply Center, Tokyo, Japan). For the eotaxin production, the cells were cultured using F12 containing 1\% fetal bovine serum and antibiotics (penicillin and streptomycin) on a collagen-coated dish with TNF- $\alpha(10 \mathrm{ng} / \mathrm{ml})$, IL-4 $(100 \mathrm{ng} / \mathrm{ml})$, or TNF- $\alpha$ plus IL-4, for $48 \mathrm{~h}$.

Reagents Recombinant human TNF- $\alpha$ was kindly provided by Dainippon Pharmaceutical Co. (Osaka, Japan). Recombinant human IL-4 was obtained from R\&D Systems (Minneapolis, MN, U.S.A.). Anti-eotaxin-1, anti-eotaxin-3 antibodies (Abs) were obtained from R\&D Systems, anti$\mathrm{NF}-\kappa \mathrm{B}$ p 65 , and anti-STAT6 Abs, and horseradish peroxidase-coupled secondary goat anti-rabbit IgG Ab were obtained from Santa Cruz Biotechnology (Santa Cruz, CA, U.S.A.). Anti-p-ERK and anti-ERK Abs were obtained from Promega (Madison, WI, U.S.A.). PD98059, U0126, SB203580 and ALLN were purchased from Sigma Chemical Co. (St. Louis, MO, U.S.A.). Bortezomib was purchased from Millennium Pharmaceuticals, Inc. (Cambridge, MA, U.S.A.).

Reverse Transcription (RT)-Polymerase Chain Reaction (PCR) and Quantitative PCR Total RNA was isolated using a QIAGEN RNeasy Mini Kit (QIAGEN). One microgram of total RNA was reverse-transcribed using a reverse transcriptase (TaKaRa) in total volume of $20 \mu \mathrm{l}$. Primers for PCR amplification were as follows: eotaxin-1:5' CCCAACCACCTGCTGCTTTAACCTG-3' $/ 5^{\prime}$-AAAAATGGTGATTATTTATGGC-3' $\quad\left(\mathrm{Tm}=55^{\circ} \mathrm{C}\right) ; \quad$ eotaxin-3:5'-CTGCTTCCAATACAGCCACA-3'/5' - TCCTCGGATGACAATTCAGC-3' $\left(\mathrm{Tm}=60^{\circ} \mathrm{C}\right)$. The PCR was performed with $200 \mathrm{~nm}$ each of sense and antisense primers under the following amplification conditions: $1 \mathrm{~min}$ at $94{ }^{\circ} \mathrm{C}, 1 \mathrm{~min}$ at temperature of $55^{\circ} \mathrm{C}$ or $60^{\circ} \mathrm{C}$, and $2 \mathrm{~min} 72^{\circ} \mathrm{C}, 25$ cycles. Quantitative PCR was performed by ABIPRISM 7700, using above cDNA, primers and SYBR Green PCR mater mix (Applied Biosystems). Glyceraldehyde-3-phosphate dehyrogenese (GAPDH) was used as a control.

ELISA for Eotaxin-1 and Eotaxin-3 and Cytotoxicity Assay ELISA tests for eotaxin-1 and eotaxin-3 were performed, following the supplier's recommendations (Quantikine, R\&D Systems). Chemokines concentrations were determined from the standard curve provided in the detection kit. Briefly, samples were loaded on the EIA plates precoated with mouse anti-eotaxin-1 Ab or eotaxin-3 Ab for two hours at $37^{\circ} \mathrm{C}$, followed by the addition of horseradish peroxidaselabeled rabbit polyclonal Abs. Finally, tetramethylbenzidine as a chromogen was added, stopped by $2 \mathrm{~N}$ sulfuric acid and absorbance was read at $450 \mathrm{~nm}$. The minimum detectable levels of eotaxin-1 and eotaxin-3 were $15.6 \mathrm{pg} / \mathrm{ml}$ and $7.6 \mathrm{pg} / \mathrm{ml}$, respectively.

The cytotoxicity of the compounds was evaluated by LDH assay. The relase of LDH in the supernatants was determined as described with the LDH-Cytotoxic test kit (Wako, Osaka, Japan).

Immunoblot Analysis HFL-1 cells were washed in icecold Dulbecco's phosphate buffered saline (PBS) and were resuspended in $200 \mu \mathrm{l}$ lysis buffer A (10 mM HEPES-KOH ( $\mathrm{pH} 7.8$ ), $10 \mathrm{~mm} \mathrm{KCl,} 0.1 \mathrm{~mm}$ EDTA (pH 8.0), 0.1\% NP-40, protease inhibitor mix, DL-dithiothreitol (DTT)), and collected by Raspador cellular (FALCON). The supernatant was collected as a cytoplasmic fraction by centrifugation. Subsequently, nuclear fraction was prepared by resuspending nuclear pellets with $100 \mu$ lysis buffer C (50 mm HEPES-KOH ( $\mathrm{pH} 7.8$ ), $420 \mathrm{~mm} \mathrm{KCl,} \mathrm{0.1} \mathrm{mм} \mathrm{EDTA} \mathrm{(pH} \mathrm{8.0),} 5 \mathrm{~mm} \mathrm{MgCl}_{2}$, $2 \%$ glycerol, protease inhibitor mix (1 mM DTT)), incubated on ice for $30 \mathrm{~min}$. The supernatant was collected as a nuclear fraction by centrifugation. The samples of equal amounts of protein $(10 \mu \mathrm{g})$ were subjected to SDS-PAGE, transferred onto a PVDF membrane, and immunoblotted as described elsewhere, ${ }^{22)}$ using affinity-purified rabbit antiserum against STAT 6 or NF- $\kappa$ B.

Statistical Analysis All of the results shown are repeated at least three times, mostly six times and represented as mean \pm S.D. Statistical analysis of the data was performed by Dunnett's test following one-way ANOVA for multiple comparison. A $p$-value less than 0.05 was considered to be statistically significant.

\section{RESULTS}

Induction of IL-8, Eotaxin-1, and Eotaxin-3 mRNA Expression in HFL-1 Cells by TNF- $\alpha$ and IL-4 Lung fibroblasts are known as a potent producer of inflammatory chemokines, and we employed HFL-1 as a human lung fibroblast cell line to study IL-8, eotaxin-1, and eotaxin-3 production as described elsewhere. ${ }^{23}$ IL-8 mRNA expression was induced by TNF- $\alpha(10 \mathrm{ng} / \mathrm{ml})$ but not by IL-4 (100 $\mathrm{ng} / \mathrm{ml}$ ) alone, while both eotaxin-1 and eotaxin-3 mRNA were induced minimally by IL- 4 but not by TNF- $\alpha$ and enhanced by the combination of TNF- $\alpha$ plus IL- 4 as shown by the RT-PCR (Fig. 1A) and by the quantitative PCR methods (Fig. 1B). While IL-8 mRNA appeared as early at 12 to $24 \mathrm{~h}$, eotaxin-1 mRNA reached a peak at 24 to $36 \mathrm{~h}$, and eotaxin-3 mRNA reached later at 36 to $48 \mathrm{~h}$, as judged by the quantitive PCR (Fig. 1B). Concomitantly, eotaxin-1 and eotaxin-3 protein production measured by ELISA reached plateau levels at 48 to $72 \mathrm{~h}$ and $96 \mathrm{~h}$, respectively. So, we incubated for $48 \mathrm{~h}$ to test eotaxin mRNA expression and protein production at $96 \mathrm{~h}$ in later experiments.

Involvement of NF- $\kappa$ B and STAT6 in TNF- $\alpha$-, IL-4-, and TNF- $\alpha+$ IL-4-Stimulated HFL-1 Cells It has been demonstrated that TNF- $\alpha$ and IL-4 lead to synergistic induction of eotaxin-1 in fibroblasts and epithelial cells, ${ }^{13,14)}$ in which the transcription factors, NF- $\kappa \mathrm{B}$ and STAT6 are involved in the TNF- $\alpha$ and IL-4-stimulated eotaxin-1 mRNA expression. ${ }^{15,24)}$ Therefore, we explored how the activation of $\mathrm{NF}-\kappa \mathrm{B}$ and STAT6 is involved in the eotaxin-1 and eotaxin-3 expression in HFL-1 cells. As shown in Fig. 2, we observed 


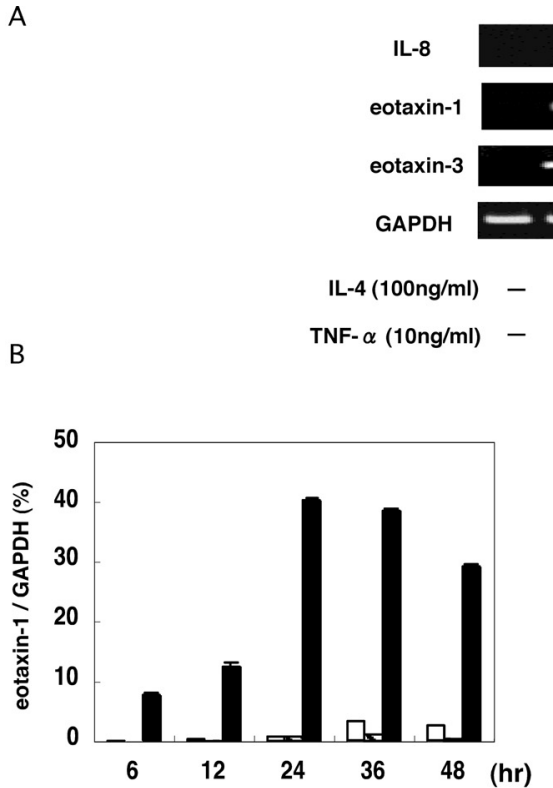

\section{$\square$ IL-4 \\ NTNF- $\alpha$}

-TNF- $\alpha+$ IL-4

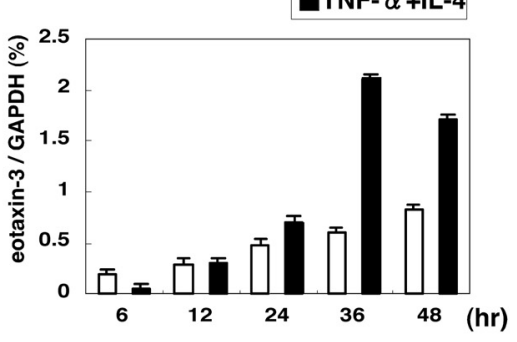

C
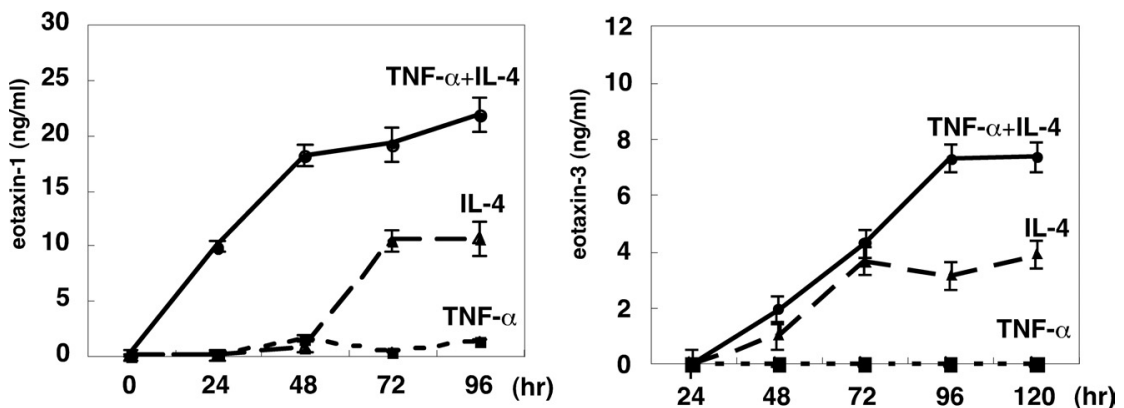

Fig. 1. Induction of IL-8, Eotaxin-1, and Eotaxin-3 in TNF- $\alpha$ or IL-4 or TNF- $\alpha+$ IL-4 Stimulated HFL-1 Cells

(A) After stimulation of HFL-1 cells with medium alone, TNF- $\alpha(10 \mathrm{ng} / \mathrm{ml})$, IL-4 (100 ng/ml), and TNF- $\alpha(10 \mathrm{ng} / \mathrm{ml})+\mathrm{IL}-4$ (100 ng/ml) for $48 \mathrm{~h}$, total RNA was isolated. RTPCR was done and their products were size-fractionated and visualized by ethidium-bromide staining in agarose gels. (B) Quantitative PCR was performed using total RNA prepared at each incubation time. (C) Eotaxin-1 and eotaxin-3 production was determined by ELISA after the incubation for $96 \mathrm{~h}$. Data are shown as the mean \pm S.D. from three independent experiments.

that NF- $\kappa$ B translocation from cytoplasm to the nuclear fraction was observed by both TNF- $\alpha$ and TNF- $\alpha$ plus IL-4 stimulation but not by the IL-4 stimulation, while STAT6 translocation from cytoplasm to the nucleus was enhanced by IL-4 and TNF- $\alpha$ plus IL-4 stimulation but not by the TNF- $\alpha$ stimulation. Thus, we confirmed that IL-4 stimulation resulted in the translocation of STAT6 to the nucleus, while $\mathrm{TNF}-\alpha$ stimulation resulted in the translocation of NF- $\kappa \mathrm{B}$ protein.

Effects of p38MAPK Inhibitor (SB203580), MEK Inhibitors (PD98059 and U0126) on Eotaxin-1 mRNA and Production by HFL-1 Cells In order to explore the signals involved in the eotaxin-1 production, we determined protein levels by ELISA and mRNA levels by RT-PCR, in the presence or absence of various inhibitors. HFL-1 cells were treated with various doses of inhibitors for $30 \mathrm{~min}$ and stimulated with TNF- $\alpha$ plus IL-4 for $96 \mathrm{~h}$. Eotaxin-1 production and mRNA expression were inhibited markedly by p38MAPK inhibitor, SB203580, but not inhibited by the MEK (MAPK/ERK kinase) inhibitors, PD98059 and U0126, up to the $30 \mu \mathrm{M}$ or $10 \mu \mathrm{M}$, respectively (Figs. 3A, B), in conditions that PD98059 at $30 \mu \mathrm{M}$ and U0126 at $10 \mu \mathrm{M}$ inhibited the ERK activation (Fig. 3C). We thus presumed that eo-

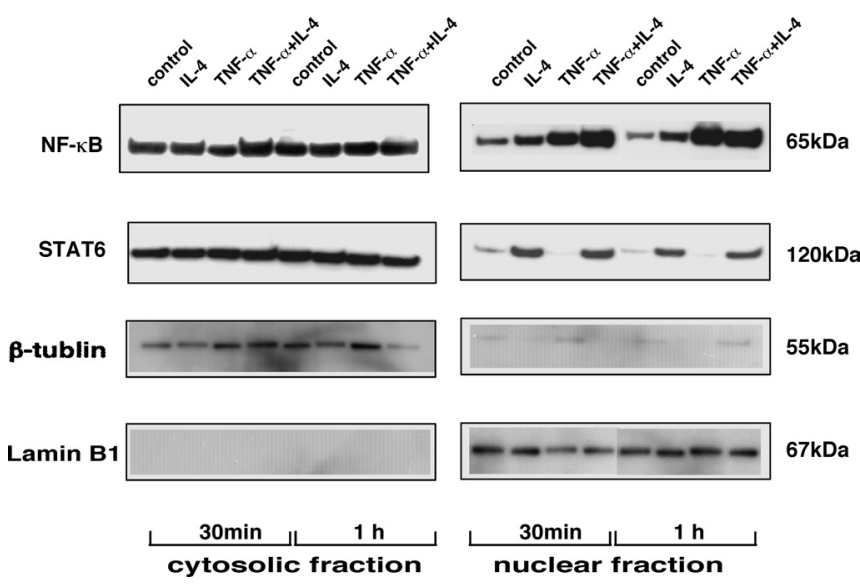

Fig. 2. Involvement of NF- $\kappa \mathrm{B}(\mathrm{p} 65)$ and STAT6 in TNF- $\alpha-$, IL-4-, and TNF- $\alpha+$ IL-4-Stimulated HFL-1 Cells

HFL- 1 cells were stimulated with the same conditions described in Fig. 1 for 30 min and $1 \mathrm{~h}$. Cell extracts for cytosolic and nuclear fractions were prepared and the extracts were subjected to $10 \%$ SDS-PAGE. Western blotting $(10 \mu \mathrm{g}$ protein/lane) was performed using anti-STAT6 $(1: 500)$, anti-NF- $\kappa$ B p65 $(1: 500)$, anti- $\beta$-tublin $(1: 1000)$ and anti-lamin B1 $(1: 1000)$ Abs, respectively. 

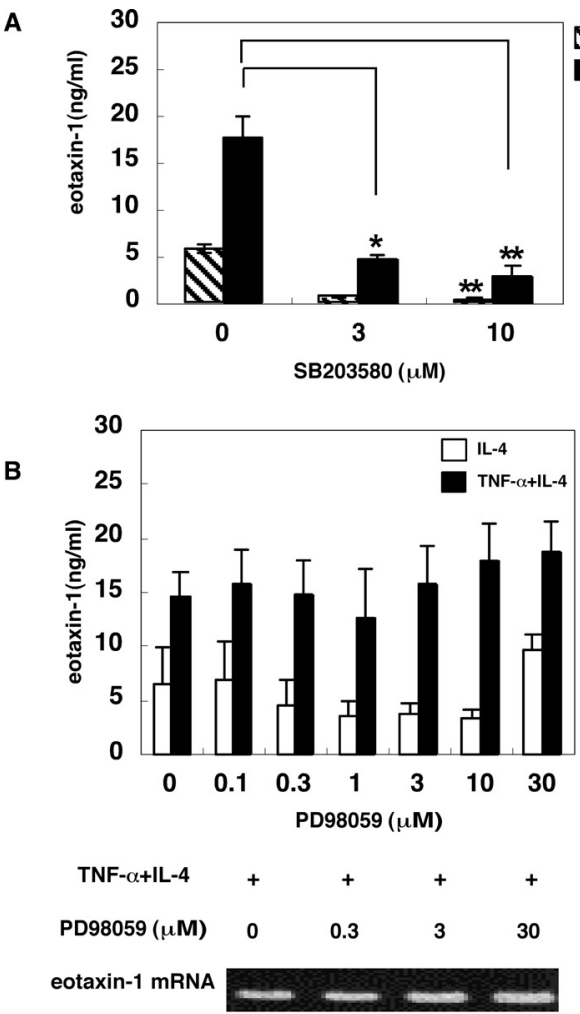

C

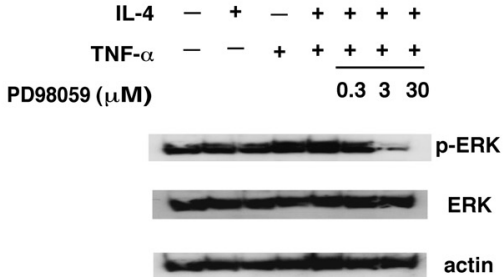

$\mathbf{N}$ TNF- $\alpha$

TNF- $\alpha+$ IL-4
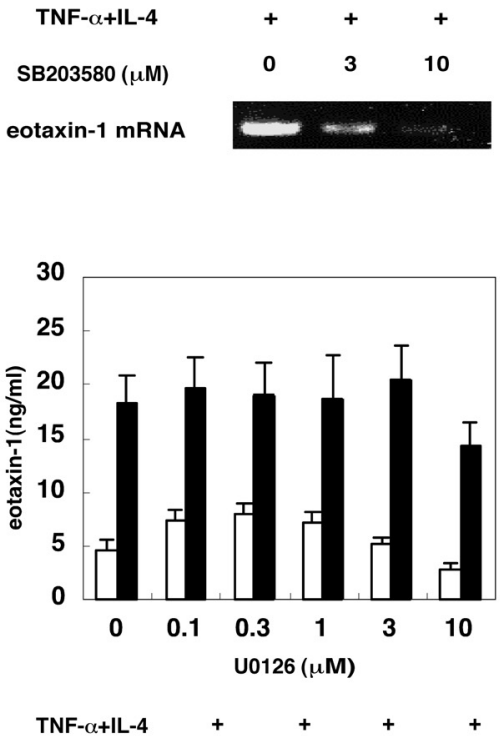

U0126 ( $\mu \mathrm{M}) \quad 0 \quad 0.1 \quad 1 \quad 10$
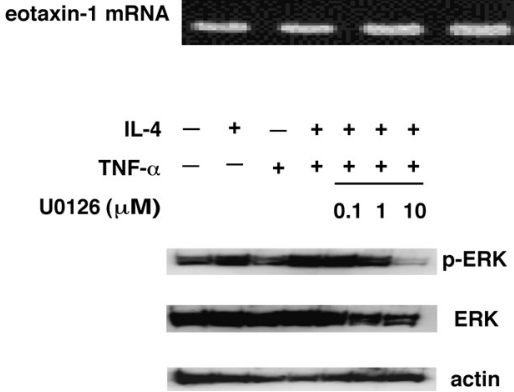

Fig. 3. Effects of p38MAPK Inhibitor (SB203580), MEK Inhibitors (PD98059 and U0126) on Eotaxin-1 mRNA and Production by TNF- $\alpha+$ IL-4-Stimulated HFL-1 Cells

(A), (B) HFL-1 cells were pretreated with PD98059, U0126 or SB203580 for 30 min prior to stimulation with $10 \mathrm{ng} / \mathrm{ml} \mathrm{TNF-} \alpha$ plus $100 \mathrm{ng} / \mathrm{ml} \mathrm{IL-4} \mathrm{for} 48 \mathrm{~h}$ or $96 \mathrm{~h}$. After $96 \mathrm{~h}$, the amount of eotaxin- 1 in the supernatants was measured by eotaxin-1 ELISA. Data are shown as the mean \pm S.D. from three independent experiments. $* p<0.05$, and $* * p<0.01$. Total RNA was isolated after $48 \mathrm{~h}$, RT-PCR was done and their products were size-fractionated and visualized by ethidium-bromide staining in agarose gels. (C) Cell extracts was prepared from HFL-1 cells. These extracts were subjected to $10 \%$ SDS-PAGE, and western blotting (10 $\mu$ g protein/lane) was performed with anti-p-ERK (1:500) and anti-ERK $(1: 500) \mathrm{Abs}$

taxin-1 gene activation is linked preferentially to the p38MAPK pathway rather than MEK/ERK pathway.

Effects of p38MAPK Inhibitor (SB203580), MEK Inhibitors (PD98059 and U0126) on Eotaxin-3 mRNA and Production by TNF- $\alpha$ plus IL-4-Stimulated HFL-1 Cells We also tested the effect on SB203580, PD980589 or U0126 on the eotaxin-3 production by HFL-1 cells. Expression of eotaxin-3 protein and mRNA levels induced by TNF- $\alpha$ plus IL-4 was down-regulated dose-dependently by SB203580 $\left(\mathrm{IC}_{50}=3 \mu \mathrm{M}\right)$, as well as by PD98059 ( $\mathrm{IC}_{50}=$ appr. $\left.20 \mu \mathrm{M}\right)$, and by $\mathrm{U} 0126\left(\mathrm{IC}_{50}=2 \mu \mathrm{M}\right)$ (Figs. 4A, B). This contrasts with the eotaxin-1 production, which is rather sensitive to the inhibition by the MEK inhibitors as indicated in Figs. 3A and B. These data suggested that activation pathway to eotaxin-3 gene and protein production is regulated by both p38MAPK and MEK/ERK pathways.

Effects of ALLN and Bortezomib on the Eotaxin-1 and Eotaxin-3 Production by TNF- $\alpha$ plus IL-4 Stimulated HFL-1 Cells Proteasome inhibitors function by stabilizing the $\mathrm{I} \kappa \mathrm{B} \alpha$ protein and then inhibiting NF- $\kappa \mathrm{B}$ activation. ${ }^{17}$
We investigated the effect of ALLN and bortezomib on production and the expression of eotaxin- 1 and -3 . HFL-1 cells were treated with various doses of ALLN and bortezomib and stimulated with TNF- $\alpha(10 \mathrm{ng} / \mathrm{ml})$ plus IL-4 $(100 \mathrm{ng} / \mathrm{ml})$ for $96 \mathrm{~h}$. Eotaxin-1 production was inhibited in dose-dependent manners by ALLN and bortezomib with $\mathrm{IC}_{50} 8 \mu \mathrm{M}$ for ALLN and $\mathrm{IC}_{50} 6 \mathrm{~nm}$ for bortezomib (Figs. 5A, E). The inhibition was confirmed at the mRNA level (Fig. 5B). It should be noted that bortezomib is more potent than ALLN, since bortezomib was effective to inhibit eotaxin production at nM level rather than $\mu \mathrm{M}$ level of ALLN. In contrast, eotaxin-3 production was not significantly inhibited at up to $10 \mu \mathrm{M}$ of ALLN $\left(\mathrm{IC}_{50}=16 \mu \mathrm{M}\right)$ and at up to $10 \mathrm{~nm}$ of bortezomib $\left(\mathrm{IC}_{50}=11 \mathrm{~nm}\right)$ (Figs. $\left.5 \mathrm{C}-\mathrm{E}\right)$. Since eotaxin production requires long incubation for $96 \mathrm{~h}$ culture, higher concentrations of ALLN (over $40 \mu \mathrm{M}$ ) and bortezomib (over $20 \mathrm{~nm}$ ) became cytotoxic on the cells. Fifty percent cytotoxicity $\left(\mathrm{CC}_{50}\right)$ was $33 \mu \mathrm{M}$ and $16 \mathrm{~nm}$ for ALLN and bortezomib cultured for $96 \mathrm{~h}$, respectively when calculated from the LDH assay shown in Fig. 5A. Under these conditions, NF- $\kappa$ B transloca- 

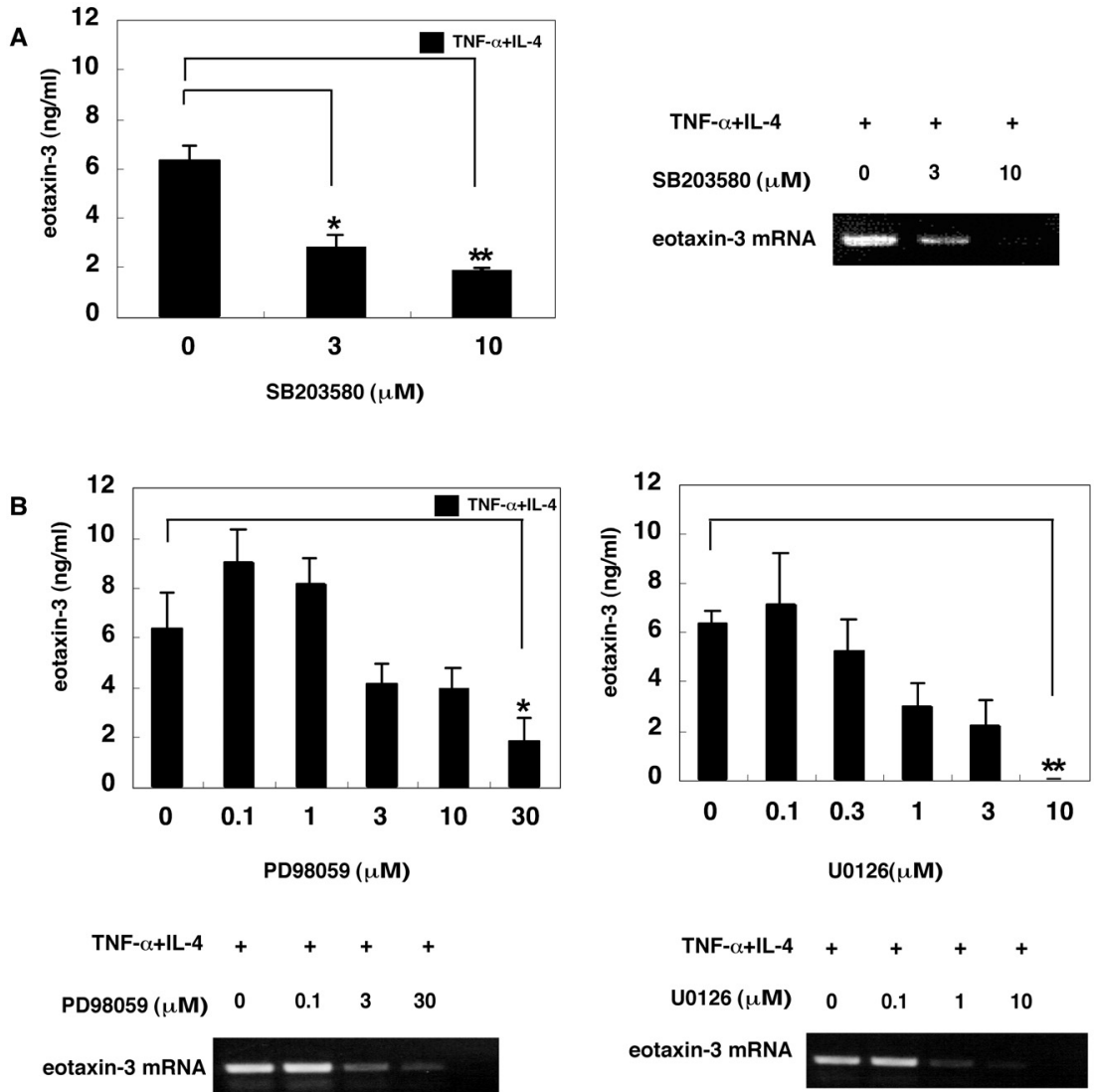

Fig. 4. Effects of p38MAPK Inhibitor (SB203580), MEK Inhibitors (PD98059 and U0126) on Eotaxin-3 mRNA and Production by TNF- $\alpha+$ IL-4-Stimulated HFL Cells

HFL-1 cells were pretreated with SB203580 (A), PD98059, U0126 (B) for $30 \mathrm{~min}$ prior to stimulation with $10 \mathrm{ng} / \mathrm{ml} \mathrm{TNF-} \alpha$ plus $100 \mathrm{ng} / \mathrm{ml} \mathrm{IL-4} \mathrm{for} 48 \mathrm{~h}$ or $96 \mathrm{~h}$. The culture medium was collected after 96 hours for eotaxin-3 ELISA assay. Data are shown as the mean \pm S.D. from six independent experiments. $* p<0.05$ and $* * p<0.01$.

tion to the nuclear was inhibited by ALLN and bortezomib by the pretreatment with $20 \mu \mathrm{M}$ ALLN and $10 \mathrm{~nm}$ bortezomib for $6 \mathrm{~h}$ (Figs. 6A, B), confirming that these drugs blocked NF- $\kappa$ B activation effectively. No inhibition of STAT6 translocation was observed in these conditions, as shown in Fig. 6A and 6B.

Synergistic Effects of SB203580 with ALLN and Bortezomib on the Eotaxin-1 But Not on Eotaxin-3 Production Finally, we explored the combined effects of the inhibitors nearly at each dose of $\mathrm{IC}_{50}$ on the eotaxin production, to see whether lower doses of these inhibitors were effective nor not. As shown in Fig. 7A, when low doses of $\operatorname{ALLN}(0,5,10$ $\left.\mu_{\mathrm{M}}\right)$ or bortezomib $(0,2.5,5,10 \mathrm{nM})$ were combined with the suboptimal doses of SB203580 $(1.5,3 \mu \mathrm{M})$, eotaxin-1 production was synergistically inhibited, particularly by the ALLN and $1.5 \mu \mathrm{M}$ but not at $3 \mu \mathrm{M}$ SB203580. Similarly, eotaxin-1 production was inhibited synergistaically by $2.5 \mathrm{~nm}$ bortezomib $1.5 \mu \mathrm{M}$ but not at $3 \mu \mathrm{M}$ SB203580. It should be noted that no significant cytotoxicity was observed at these doses (Fig. 7A, LDH (\%)). No, or if only, weak synergism between SB203580 and ALLN or bortezomib was observed in eotaxin-3 production except in low dose of SB203580 (1.5 $\mu \mathrm{M}$ ) and with $10 \mathrm{~nm}$ bortezomib (Fig. 7B). Thus, the combined use of inhibitors interfering p38MAPK and NF- $\kappa$ B pathway results in the synergistic inhibition particularly of eotaxin-1 production but not of eotaxin-3.

\section{DISCUSSION}

Several reports indicated that the eotaxin family (eotaxin1/CCL11, eotaxin-2/CCL24 and eotaxin-3/CCL26) is produced in dermal fibroblast and bronchial epithelial cells. ${ }^{13,14)}$ We also reported that both inflammatory chemokines, IL-8 and eotaxin- 1 were produced in HFL-1 cells. ${ }^{23}$ ) While we found that both eotaxin- 1 and eotaxin- 3 but not eotaxin-2 were produced in the HFL- cells (data not shown), we were interested in how the production of these two eotaxin families are regulated using several inhibitors. Differential induction of CC chemokines including eotaxin-1, -2 -3 has been demonstrated in the human dermal fibroblasts, with the rank order of expression levels of eotaxin-1, eotaxin-3 and eotaxin-2. ${ }^{26)}$ Similarly, Komiya et al. also reported concerted expression of eotaxin-1, eotaxin-2 and eotaxin-3 in human bronchial epithelial cells in response to IL-4. ${ }^{27)}$ We observed the production and mRNA expression of eotaxin- 1 and -3 but not eotaxin-2 in the human lung fibroblast HFL-1. While Dulkys et al. reported the expression of eotaxin-2 mRNA as well as eotaxin-1 and eotaxin-3 mRNA in the human dermal fibroblasts, ${ }^{26)}$ the expression of eotaxin-2 mRNA was much lower than those of eotaxin-1 and eotaxin- 3 and no protein level was confirmed, suggesting that role of eotaxin-2 was minimal in the lung or dermal fibroblasts.

Since eotaxin families play roles to recruit eosinophils at the peribronchial sites at the bronchial asthma, the drugs regulating eotaxin production are of clinical significance. We 

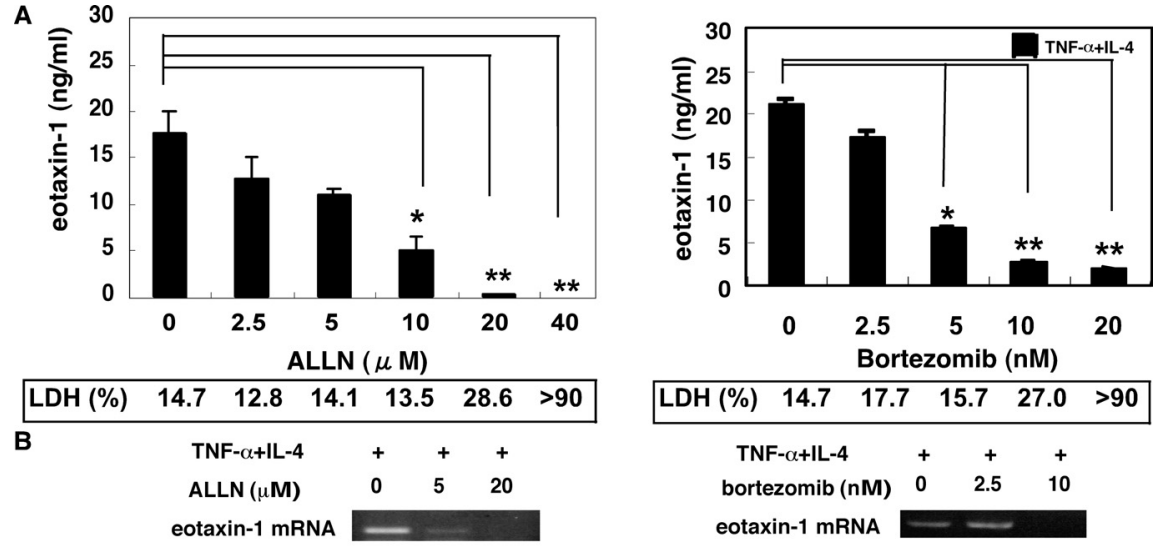

C
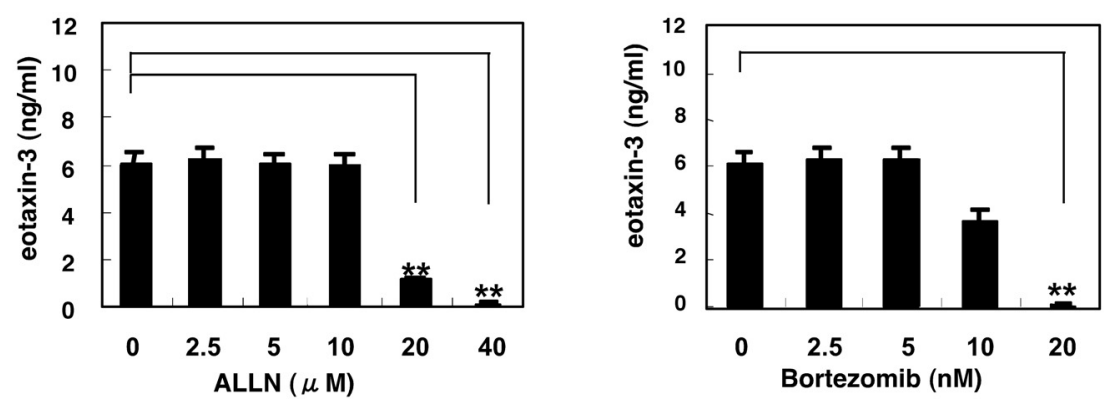

D
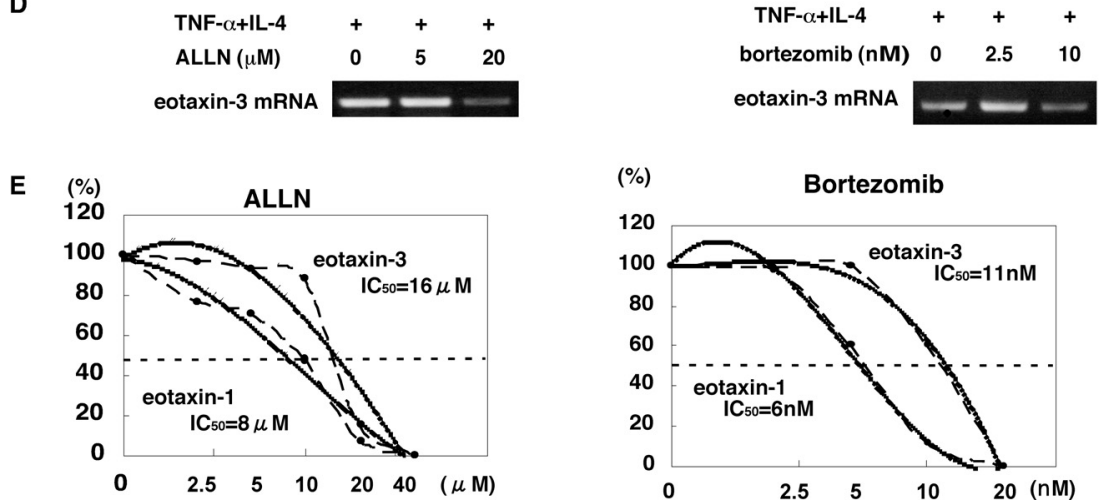

Fig. 5. Effects of ALLN and Bortezomib on Eotaxin-1 and Eotaxin-3 Productions by TNF- $\alpha$ Plus IL-4 Stimulated HFL-1 Cells

(A), (C) HFL-1 cells were treated with various doses of ALLN ( 0 to $40 \mathrm{M}$ ) and bortezomib ( 0 to $20 \mathrm{nM}$ ) for $30 \mathrm{~min}$ prior to $10 \mathrm{ng} / \mathrm{ml} \mathrm{TNF}-\alpha$ plus $100 \mathrm{ng} / \mathrm{ml} \mathrm{IL}-4 \mathrm{stimulation}$ and supernatants were collected for $96 \mathrm{~h}$. The amount of eotaxin- 1 and eotaxin-3 in the supernatants was measured by ELISA. LDH release after $96 \mathrm{~h}$-incubation was determined as the methods described in Materials and Methods. Data are shown as the mean \pm S.D. from four independent experiments. $* p<0.05$ and $* * p<0.01$. (B), (D) Total RNA was isolated after $48 \mathrm{~h}$, and the PCR products were size-fractionated. (E) $\mathrm{IC}_{50}$ was calculated based on the data shown in (A) and (C), in which dotted lines are based on the actual data and solid lines are proximate ones.

observed here several interesting findings on the differential induction of eotaxin family. First, we observed that eotaxin-1 production and mRNA expression were inhibited by p38MAPK kinase inhibitor, SB203580, but not inhibited at up to PD98059 at $30 \mu \mathrm{M}$ or U0126 at $10 \mu \mathrm{M}$, respectively. In contrast, eotaxin-3 production and mRNA expression were inhibited similarly by SB203580, PD98059 and U0126 (Fig. 4). These observations suggested that the activation of eotaxin-1 gene is more dependent on the p38MAPK pathway, while that of eotaxin-3 requires both the MEK/ERK and p38MAPK pathways.

Secondly, we observed that there are some differences on the sensitivity to the two proteasome inhibitors, ALLN $^{18)}$ and bortezomib. ${ }^{19,20)}$ Generally, bortezomib which inhibited eotaxin-1 production at the nM level, inhibited eotaxin production more effectively than ALLN, which inhibited at the $\mu \mathrm{M}$ level. Of note is that eotaxin-1 production was more sensitive to the inhibition by proteasome inhibitors, ALLN and bortezomib, than eotaxin-3 production (Figs. 5A, C), indicating that NF- $\kappa \mathrm{B}$ activation is involved more in the eotaxin- 1 than the eotaxin-3 production. An important regulatory role of STAT6 upon IL-4 stimulation has recently been described for the eotaxin-1 and eotaxin-3 genes. ${ }^{24,25,28)}$ Recently, production of eotaxin-2/CCL24 and eotaxin-3/CCL26 in a human keratinocyte cell line, $\mathrm{HaCaT}$ cells were induced by TNF- $\alpha$ and enhanced strongly with IL-4 and IL-13. ${ }^{25)}$ Production of eotaxin-3 was inhibited by inhibitors including dexamethasone, IFN- $\gamma$, or JNK inhibitor, and partially by a p38MAPK inhibitor, SB202190 but not by NF- $\kappa$ B inhibitors. ${ }^{25)}$ Partial inhibition by $\mathrm{p} 38 \mathrm{MAPK}$ inhibitor and the relative resistance against the NF- $\kappa \mathrm{B}$ inhibitors appear to be consistent to our observation that eotaxin-3 is rather resistant to the NF- $\kappa \mathrm{B}$ in- 


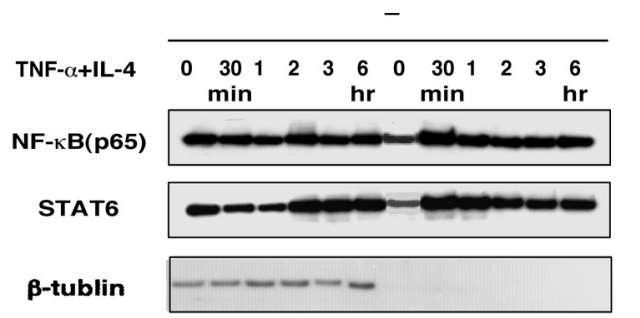

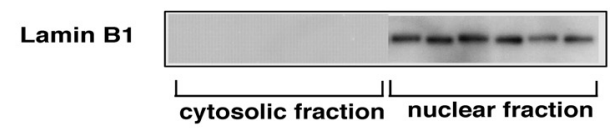

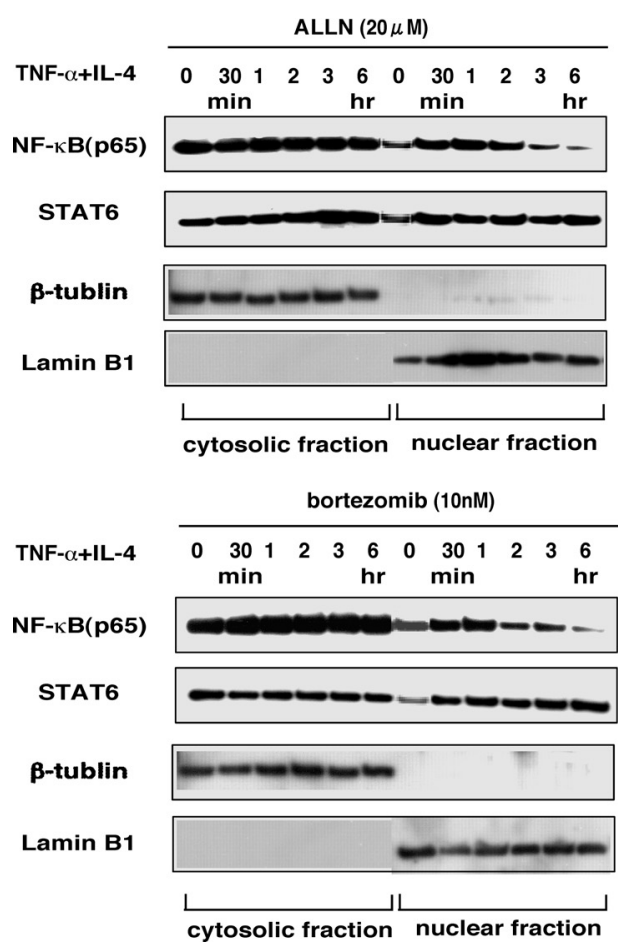

Fig. 6. Effects of ALLN and Bortezomib on NF- $\kappa$ B and STAT6 Activation in HFL-1 Cells

(A), (B) HFL-1 cells were treated with $20 \mu \mathrm{m}$ of ALLN and $10 \mathrm{nM}$ of bortezomib for $30 \mathrm{~min}$ before $10 \mathrm{ng} / \mathrm{ml}$ TNF- $\alpha$ plus $100 \mathrm{ng} / \mathrm{ml} \mathrm{IL-4} \mathrm{stimulation} \mathrm{at} \mathrm{the} \mathrm{indicated} \mathrm{times.} \mathrm{The} \mathrm{HFL-1}$ cells were fractionated by cytosolic and nuclear fraction. These extracts were subjected to $10 \%$ SDS-PAGE, and Western blotting $(10 \mu \mathrm{g}$ protein/lane) was performed with antiSTAT6 $(1: 500)$, anti-NF- $\kappa \mathrm{B}(1: 500)$ anti- $\beta$-tublin $(1: 1000)$ and anti-lamin B1 (1:1000) Abs, respectively.
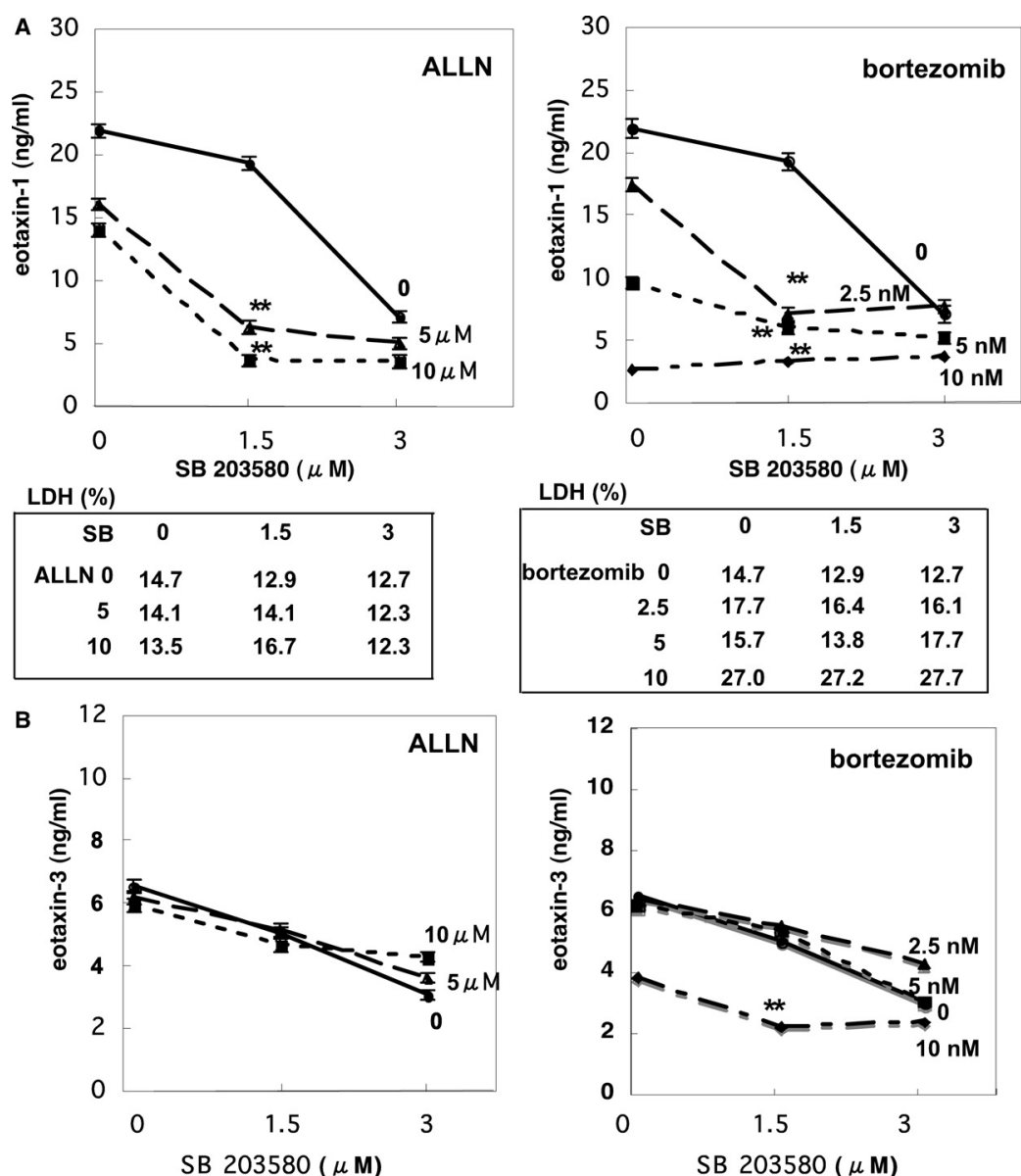

Fig. 7. Combined Effects of SB203580 and ALLN and Bortezomib on the Eotaxin-1 and Eotaxin-3 Production

(A), (B) HFL-1 cells were treated either with SB203580 $(0,1.5,3 \mu \mathrm{M})$, bortezomib $(0,2.5,5,10 \mathrm{nM})$, ALLN $(0,5,10 \mu \mathrm{M})$, or with their combination and the TNF- $\alpha$ and IL-4-induced production of eotaxin- 1 and eotaxin-3 was determined. Eotaxins in the supernatants were measured by ELISA. LDH assay was measured as described in Materials and Methods on 96h. Data are shown as the mean \pm S.D. from six independent experiments. hibitors compared to the eotaxin-1 production.

We observed significant differences in the regulation of the two eotaxin genes in response to TNF- $\alpha$. Eotaxin-1 expression can be stimulated in fibroblasts by TNF- $\alpha$ alone, whereas eotaxin-3 production could not be triggered by this cytokine. The synergistic effect may be related to the presence of an NF- $\kappa \mathrm{B}$ binding site in the eotaxin-1 promoter, which overlaps with the STAT6 site. No such structural feature was observed around the STAT6 site in the eotaxin-3 promoter. ${ }^{24)}$ Namely, TNF- $\alpha$ does not appear to play a role in the regulation of eotaxin-3 gene, whereas it is an important regulator of eotaxin-1 gene expression. It is thus possible that eotaxin-1 is produced early during the onset of an allergic immune response through the action of the proinflammatory cytokine TNF- $\alpha$. In contrast, eotaxin-3 may only be synthe- sized later in the face of a robust $\mathrm{Th} 2$ response characterized by high levels of IL-4 or IL-13.

In addition, eotaxin- 1 but not eotaxin- 3 production is synergistically inhibited by the combined treatment of the SB203580 and ALLN or SB203580 and bortezomib, indicating the effective inhibition was achieved by the combined treatment of these drugs. It should be noted that combination of ALLN or bortezomib with SB203580 each nearly at $\mathrm{IC}_{50}$ dose, provided significant inhibition of eotaxin-1 production, while no such significant synergism was observed in eotaxin3 production. Since production level of eotaxin-1 is higher than eotaxin- $3^{23)}$ as was true in our experiments, inhibition of eotaxin-1 will be useful for the inhibition of eotaxin activity. Alternatively, the eotaxin-3 is presumed to be produced at later stages, the regulation of eotaxin- 3 is important for the 
regulation of late stages in allergic inflammation including asthma. Recently, it has been suggested that eotaxin-1 is an important mediator in the early phase of allergen-induced recruitment of eosinophils into the airways, while eotaxin-2 and eotaxin-3 might play a role in the subsequent persistence of allergen-induced bronchial eosinophilia. ${ }^{29)}$ In this sense, the inhibitors against STAT6 activation may be useful for the regulation of persistent allergen-induced eosinophilia. While specific inhibitors against STAT6 transcription would be favorable for treating allergic diseases, such reagents are not available at present. We recently reported that the heteo-30OH-GL, a glycyrrhizin derivative, inhibits IL-4-mediated STAT6 activation and subsequent eotaxin-1 production, although no experiments have yet been done on the eotaxin-3 prodution. ${ }^{30)}$ Specific inhibitors against STAT6 which is critical for IL-4 and IL-13-mediated but not TNF- $\alpha$-mediated responses, should be developed to regulate the allergic inflammation.

The activation of NF- $\kappa \mathrm{B}$ is useful as a marker for the severity of allergic inflammation in certain diseases. Specific inhibitors of NF- $\kappa \mathrm{B}$ will be beneficial in the regulation of allergic responses as well as other inflammatory responses. Theoretically, if IL-4- or IL-13-mediated pathways or IL-5 pathways are blocked, eosinophilia may be regulated. However, in the allergic inflammatory sites, many other cytokines including TNF- $\alpha$ are involved, therefore, anti-inflammatory drugs regulating NF- $\kappa \mathrm{B}$ activation are required. Actually, airway epithelium display robust $\mathrm{NF}-\kappa \mathrm{B}$ activation and represent targets for anti-inflammatory asthma therapies, since transgenic mice in which NF- $\kappa \mathrm{B}$ activation is repressed, exhibited significantly ameliorated inflammation, reduced levels of chemokines, T cell cytokines, mucus cell metaplasia, and of circulating $\operatorname{IgE}$ in response to inhaled antigen. ${ }^{31)}$ Therefore, proteasome inhibitors that inhibit NF- $\kappa \mathrm{B}$ activation may be useful also for the allergic therapy. While proteasome inhibitors have nospecific cytotoxic effects on many cells, the combined use of other signal inhibitors may be useful to reduce cytotoxic effects as shown in this study. Thus, inhibitors against NF- $\kappa \mathrm{B}$ suppress overall synergistic activation between TNF- $\alpha$ and IL-4, resulting in the downregulation of eotaxin-1 production which attenuates the chemotaxis and accumulation of eosinophils in the local allergic sites including airway epithelium.

\section{REFERENCES}

1) Williams T. J., Sabore I., “Cytokine Reference,” Vol. 1, ed. by Oppenheim J. J., Feldman M., Academic Press, San Diego, 2001, pp. 12151226.

2) Ponath P. D., Qin S., Post T. W., Wang J., Wu L., Gerard N. P., Newman W., Gerard C., Mackay C. R., J. Exp. Med., 183, 2437-2448 (1996).

3) Luster A. D., N. Engl. J. Med., 338, 436- 445 (1998).

4) Jose P. J., Griffiths-Johnson D. A., Collins P. D., Walsh D. T., Moqbel R., Totty N. F., Truong O., Hsuan J. J., Williams T. J., J. Exp. Med.,
179, 881-887 (1994).

5) Foessmann U., Uguccioni M., Loescher P., Dahinden C. A., Langen H., Thelen M., Baggiolini M., J. Exp. Med., 185, 2171-2176 (1997).

6) Shinkai A., Yoshisue H., Koike M., Shoji E., Nakagawa S., Saito A., Takeda T., Imabeppu S., Kato Y., Hanai N., Anazawa H., Kuga T., Nishi T., J. Immunol., 163, 1602-1610 (1999).

7) Zimmermann N., Hogan S. P., Mishra A., Brandt E. B., Bodette T. R., Pope S. M., Finkelman F. D. Rosenberg M. E., J. Immunol., 165, $5839-5846(2000)$.

8) Vecchiarelli A., Siracusa A., Cenci E., Puliti M., Abbritti G., Clin Exp. Allergy, 22, 365-370 (1992).

9) Wallach D., Varfolomeev E. E., Malinin N. L., Goltsev Y. V., Kovalenko A. V., Boldin M. P., Annu. Rev. Immunol., 17, 331-367 (1999).

10) Brown M. A., Pierce J. H., Watson C. J., Falco J., Ihle J. N., Paul W. E., Cell, 50, 809-818 (1987).

11) Seder R. A., Paul W. E., Ben-Sasson S. Z., LeGros G. S., Kagey S. A., Finkelman F. D., Pierce J. H., Plaut M., Int. Arch. Allergy Appl. Immunol., 94, 137-140 (1991).

12) Keegan A. D., “Cytokine Reference," Vol. 1, ed. by Oppenheim J. J., Feldmann M., Academic Press, San Diego, 2001, pp.127-135.

13) Mochizuki M., Bartels J., Mallet A. I., Christophers E., Schroder J. M., J. Immunol., 160, 60-68 (1998).

14) Stellato C., Matsukura S., Fal A., White J., Beck L. A., Proud D., Schleimer R. P., J. Immunol., 163, 5624-5632 (1999).

15) Matsukura S., Stellato C., Plitt J.R., Bickel C., Miura K., Georas S. N., Casolaro V., Schleimer R. P., J. Immunol., 163, 6876-6883 (1999).

16) Wong C. K., Zhang J. P., Ip W. K., Lam W. K., Clin. Exp. Immunol., 128, 483-489 (2002).

17) Murray R. Z., Norbury C., Anticancer Drugs, 11, 407-417 (2000).

18) Vinitsky A., Michaud C., Powers J. C., Orlowski M., Biochemistry, 31, 9421-9428 (1992).

19) Palombella V. J., Conner E. M., Fuseler J. W., Destree A., Davis J. M., Laroux F. S., Wolf R. E., Huang J., Brand S., Elliott P. J., Lazarus D., McCormack T., Parent L., Stein R., Adams J., Grisham M. B., Proc. Natl. Acad. Sci. U.S.A., 95, 15671-15676 (1998).

20) Sunwoo J. B., Chen Z., Dong G., Yeh N., Bancroft C., Sausville E., Adams J., Elliott P., Waes C. V., Clin. Cancer Res., 7, 1419-1428 (2001).

21) Hidesima T., Richardson P., Chauhan D., Palombella V. J., Elliott P. J., Adams J., Anderson K.C., Cancer Res., 61, 3071-3076 (2001).

22) Funakoshi M., Tago K., Sonoda Y., Tominaga S., Kasahara T., Biochem. Biophys. Res. Commun., 283, 248-254 (2001).

23) Matsui S., Matsumoto H., Sonoda Y., Aizu-Yokota E., Sato T., Kasahara T., Int. Immunopharmacol., 4, 1633-1644 (2004).

24) Hoeck J., Woisetschlager M., J. Immunol., 167, 3216-3222 (2001).

25) Kagami S., Saeki H., Komine M., Takanuma T., Tsunemi Y., Nakamura K., Sasaki K., Asahina A., Tamaki K., Clin. Exptl. Immunol., 141, 456- 466 (2005)

26) Dulkys Y., Schramm G., Kimmig D., Knob S., Weyergraf A., Kappa A., Elsner J., J. Invest. Dermatol., 116, 498-505 (2001).

27) Komiya A., Nagase H., Yamada H., Sekiya T., Yamaguchi M., Sano Y., Hanai N., Furuya A., Ohata K., Matsushima K., Yoshie O., Yamamoto K., Hirai K., Cell. Immunol., 225, 91-100 (2003).

28) Hoeck J., Woisetschlager M., J. Immunol., 166, 4507-4515 (2001).

29) Ravensberg A. J., Ricciardolo F. L., van Schadewijk A., Rabe K. F., Sterk P. J., Hiemstra P. S., Mauad T., J. Allergy Clin. Immunol., 115, 779-785 (2005)

30) Matsui S., Sonoda Y., Sekiya T., Aizu-Yokota E., Kasahara T., Intl. Immunopharm., 6, 369-375 (2006).

31) Poynter M. E., Cloots R., van Woerkom T., Butnor K. J., Vacek P., Taatjes D. J., Irvin C. G., Janssen-Heininger Y. M., J. Immunol., 173, 7003-7009 (2004). 